Mining University. - 2013. - Issue 2. - Р. 11. 8. Моркун В. С. Оптимизация управления качеством железорудной продукции на основе ультразвукового контроля / В. С. Моркун, O. В. Поркуян // Научный журнал «Материалы IV Международной конференции «Стратегия качества в промышленности и образовании».- Болгария- Варна, Технич. ун-т, 2009. C. 143-147. 9. Купін А. I. Інтелектуальна ідентифікація та керування в умовах процесів збагачувальної технології : [монографія] / Андрій Іванович Купін. - Кривий Ріг : КТУ. 2008. - 204 с. 10. Концепція державної програми роботи з обдарованою молоддю на 20062010 роки // Освіта України. - 2006. - № 48 (741). - С. 1-3. 11. Державна цільова науковотехнічна та соціальна програма «Наука в університетах» на 2008-2012 роки [Електронний pecypc]/ Кабінет Міністрів України. - Офіц. вид. - Київ, 2007. - Режим доступу : http://zakon1.rada.gov.ua

УДК 378.937

Анжселіка Татарнікова

\title{
ПЕДАГОГІЧНІ УМОВИ ФОРМУВАННЯ ПРОФЕСІЙНОЇ КОМПЕТЕНТНОСТІ СТУДЕНТІВ МУЗИЧНИХ СПЕЦІАЛЬНОСТЕЙ 3 АРТ-МЕНЕДЖМЕНТУ
}

Татарнікова А. А. Педагогічні умови формування професійної компетентності студентів музичних спеціальностей з арт-менеджменту.

У статті на основі аналізу й узагальнення концептуальних підходів зарубіжних та українських науковців щодо сутності навчальних програм 3 арт-менеджменту, а також модернізації мистецької освіти, обгрунтовано педагогічні умови формування професійної компетентності студентів музичних спеціальностей 3 арт-менеджменту. Продемонстровано значущість професійної підготовки студентів музичних спеціальностей як майбутніх артменеджерів, розкрито дидактичний потенціал провідних принципів i засобів компетентнісного й студентоцентрованого підходів щодо ii організації й оцінки якості прикінцевих результатів.

Ключові слова: арт-менеджмент, професійна компетентність 3 арт-менеджменту, компетентнісний підхід, студентоцентрований підхід, фахова підготовка студентів музичних спеціальностей.

Татарникова А. А. Педагогические условия формирования профессиональной компетентности студентов музыкальных специальностей по арт-менеджменту.

В статье на основе анализа концептуальных подходов зарубежных и украинских ученых к исследованию сущности учебных программ по арт-менеджменту, а также модернизации художественного образования, обоснованы педагогические условия формирования профессиональной компетентности студентов музыкальных специальностей по арт-мененджменту. Продемонстрирована значимость профессиональной подготовки студентов музыкальных специальностей как будущих арт-менеджеров, раскрыт дидактический потенциал ведущих принципов и средств компетентностного и студентоцентрированного подходов к ее организации и оценке качества результатов.

Ключевые слова: арт-менеджмент, профессиональная компетентность по артменеджменту, компетентностный подход, студентоцентрированный подход, профессиональная подготовка студентов музыкальных специальностей.

Tatarnikova A. A. Pedagogical conditions of professional competence development of music students in Arts Management.

This article comprises the substantiation of the pedagogical conditions of professional competence development of music students in Arts Management based on the analysis of the conceptual approaches of foreign and Ukrainian scientists to educational programmes' research in Arts Management, as well as the modernisation of professional music education system. The importance of the vocational training of music students who are to become Arts Managers is also 
demonstrated in the article. The future specialists have to obtain the leading technologies of Arts Managements, i.e. promotion of Arts product, concert administration, information support of Arts product and performer's creative work, Internet promotional campaigns, operating a blog in social networks, collaboration with sponsors (fundraising, patronage, and charity), etc.

It is emphasized that the analysis of educational curricula and programmes, as well as the empirical study on the levels of professional competence of musicians-alumni in Arts Management in Ukraine conclusively confirm the fact that the intentional development of the alumnus individuality like a professional Arts Manager in the field of musical art until now has not been provided in a proper manner. Therefore, the didactical potential of the main principles and means of competency-based and concentrated-on-student approaches to its organisation and the results' quality evaluation is reached.

It is also proved that the development of the professional competence of music students in Arts Management while receiving their degree in Music will take place more effectively if some special pedagogical conditions are managed to be created during the education process. These conditions are the enrichment of contents of Arts education with the theoretical questions of Arts Management, the maintenance of the individual research activities of students on gaining the main technologies of Arts Management, the pedagogical support of individual professional selfdevelopment of students as Arts Managers in the field of the Art of Music, and the motivation of students in their participation in different projects based on the artistic and creative activities.

It is shown that the means of the concentrated-on-student approach, like the principles of humanization, individualization, personalization, dialogization, scientificity, occupational mobility, contextuality of education, diversification of artistic education, its universality, adequacy to its contents, forms and methods of contemporary targets and functions of musician-specialist as an Arts Manager, the combination of pedagogical facilitation and the development of initiatives and leadership of the members of the social and cultural environment, the problemacity and situatedness of education, its close relation to the Arts Management practice, contribute to the practical realization of the indicated pedagogical conditions.

Key words: Arts Management, professional competence in Arts Management, competencybased approach, concentrated-on-student approach, vocational training of music students.

У країнах світу з усталеною ринковою економікою, де інтенсивно розвивається мистецький бізнес і потрібно серйозно конкурувати за клієнтів і споживачів, професія артменеджера 3 кожним роком стає все більш затребуваною. Це передусім вимагає неперервного вдосконалення його професійної підготовки як на бакалаврському, так i магістерському рівнях освіти. Здобуваючи певний академічний ступінь упродовж опанування відповідної професійної програми, сучасний арт-менеджер повинен продемонструвати володіння певними функціональними компетенціями: дизайнерською, що грунтується на знанні базових законів дизайну, потребуючи розвитку художньо-естетичного смаку і відчуття прекрасного; маркетинговою, спрямованою на обгрунтування цікавої концепції та розроблення відповідних рекламних кампаній; ораторською, що дозволяє артфахівцю бути переконливим і наполегливим, доводячи всім, що саме ця ідея забезпечить компанії прибуток; управлінською, яка спрямовує його активні дії й певні лідерські якості на те, щоб домогтися від своєї команди кращих результатів; креативною, що, блокуючи мислення штампами, сприяє пропонуванню нових ідей, нестандартних рекламних ходів $\mathrm{i}$ художньо-естетичних концепцій, розпочинаючи від формування творчої ідеї до реалізації готового культурного продукту. Означені функціональні компетенції, які зарубіжними вченими (П. Бендихен [11], Дж. Лідстоун [3], П. Дьюї, Дж. Річ [6]) визначаються як здатність успішно застосовувати знання, уміння та особистісні якості в конкретних умовах професійної діяльності, розуміються як вагомий результат професійної мистецької освіти, тому що іiі основна мета полягає в тому, щоб розвивати у студентів - майбутніх артменеджерів спроможність приймати власні рішення, забезпечуючи привабливість i прибутковість арт-проектів. 
Як зазначають українські науковці (О. Безгін, Г. Бернадська, О. Дацко, І. Кочарян, М. Поплавський, О. Успенська, О. Часник), орієнтація на світові й європейські освітні цінності вимагає значних перетворень й на рівні вітчизняних навчальних закладів мистецької освіти, оскільки українське суспільство висуває нові вимоги стосовно ії модернізаційних змін, зокрема в контексті організації професійної підготовки студентів як майбутніх артменеджерів у нашій країні. До провідних технологій арт-менеджменту, які повинен опанувати майбутній лідер у сфері культури й мистецтва, дослідники (К. Жданова, Ф. Колбер, О. Командишко, С. Корнєєва, Ф. Котлер, Г. Новикова, Г. Тульчинський, А. Якупов) зараховують такі: просування арт-продукту; концертне адміністрування; інформаційну підтримку арт-продукту й творчої діяльності виконавця (організація та ведення рекламних кампаній, інформаційна та рекламна розсилка в усій базі учасників eventринку); промо-кампанії в Інтернеті (розміщення банерів, новин та відеоновин у стрічках новин, розсилка прес-релізів і новин у ЗМІ та професійним дописувачам); ведення блогів у соціальних мережах; робота із спонсорами (файндрайзинг, меценатство, добродійність) тощо. Натомість аналіз навчальних планів і програм, а також емпіричне дослідження рівнів професійної компетентності випускників-музикантів 3 арт-менеджменту, переконливо засвідчують, що цілеспрямованого формування особистості випускника як професійно обізнаного арт-мененджера 3 музичного мистецтва до теперішнього часу не відбувається належно [5, с. 45].

3 огляду на відсутність науково обгрунтованої дидактичної концепції формування особистості арт-мененджера у вищих навчальних закладах культури та мистецтва, мета cmammi полягає в обгрунтуванні педагогічних умов формування професійної компетентності студентів музичних спеціальностей з арт-менеджменту.

Одним із вирішальних чинників, які перешкоджають отриманню сучасної освіти менеджерами культури в Україні, зазначають О. Безгін і Г.Бернадська [5], є загальна відсутність академічних навчальних програм 3 мистецького менеджменту. Хоча децентралізація, комерціалізація та інтернаціоналізація української галузі культури вимагають від менеджерів поєднання знань у галузі мистецтва й управління, вітчизняні вищі навчальні заклади культури і мистецтв дещо відстали з відповіддю на ці вимоги. Це автори пояснюють тим, що менеджмент культури як самостійна дисципліна ще не повністю введений в Україні. Не тільки традиційні університети, а й художні школи часто відмовляються сприймати унікальний і самодостатній характер менеджменту культури як професійної кваліфікації, не враховують його потенціалу на ринку праці [5, с. 48].

Нині, за даними каталогу вищої освіти України, є дев'ять програм, які належать до менеджменту культури, чотири з яких функціонують у вищих навчальних закладах столиці (Київському національному університеті театру, кіно і телебачення імені І. К. КарпенкаКарого; Київському національному університеті культури і мистецтв; Національній академії керівних кадрів культури і мистецтв; Національній академії образотворчого мистецтва i архітектури), три - в обласних центрах сходу України (Харківській державній академії культури; Харківському національному університеті мистецтв; Луганському державному інституті культури і мистецтв). Також діє програма 3 менеджменту культури на факультеті культури і мистецтв Львівського національного університету імені Івана Франка, яка, включаючи один або два курси з управління, вважається обов'язковою умовою навчання майбутніх театрознавців через їх ознайомлення з виробничим і творчим життям професійних театрів, із процесом створення та реалізації вистави, з безпосередньою роботою театральних митців, тому включають один або два курси управління в свої навчальні програми. Окрім того, програма навчання менеджменту культури існує на гуманітарному факультеті Одеського національного політехнічного університету.

Вочевидь, констатують О. Безгін і Г. Бернадська [5], більшість програм були створені в державних спеціалізованих вищих навчальних закладах мистецтва чи гуманітарних вищих навчальних закладах. Ураховуючи нестачу відповідної інформації, важко здійснювати глибокий аналіз цих програм, їх структури, змісту і якості, а також оцінити їх можливості. 
Залежно від профілю навчального закладу, такі програми мають домінантну наявність курсів або з теорії та історії мистецтв, або з економіки, доповнені кількома вибірковими курсами, пов’язаними 3 конкретною галуззю мистецтва. У більшості мистецьких вищих навчальних закладів ці програми існують у вигляді поєднання в ширшому контексті мистецтва, культурології, гуманітарних наук або наук загального управління. Оскільки моніторинг структури і змісту цих програм та їх оцінка ніколи не здійснювались, то якість освіти, яку вони забезпечують, залишається під питанням. Це, на думку О. Безгіна і Г. Бернадської [5], ставиться під сумнів визнання отриманих студентами освітньо-кваліфікаційних рівнів в інших країнах. Натомість, важливо, щоб ці програми наближалися до змісту програм провідних університетів світу, які готують фахівців з мистецького менеджменту, сприяли працевлаштуванню випускників та полегшували їх академічне визнання як основу для подальших досліджень.

Хоча перша програма в галузі організації та управління мистецтвом була створена в Україні майже чотири десятиліття тому, зазначають О. Безгін і Г. Бернадська [5], питання про легітимність в Україні менеджменту культури й соціально-культурної діяльності, а також арт-мененджменту і музичного мененджменту як академічних дисциплін донині залишається остаточно не розв'язаним, не зважаючи на те, що воно неодноразово порушувалися й обговорювалися фахівцями, які розробляли робочі програми означених курсів і елективних спецкурсів. Основну причину такого стану науковці вбачають у відсутності інформаційних ресурсів з поширення знань у галузі культурного, мистецького й музичного менеджменту [1, с. 45].

За словами Дж. Лідстоун [3, с. 6], наукові конференції та публікації у профільних журналах $\epsilon$ важливими передумовами набуття знань з менеджменту культури та створення теоретичної бази для навчальних програм. Відсутність в Україні професійних видань 3 менеджменту культури, мала кількість конференцій, відсутність інших інформаційних ресурсів гальмують формування теоретичної бази для створення та вдосконалення навчальних програм й уповільнюють поширення знань 3 менеджменту культури серед педагогів і практиків. Окрім того, бракує професійної мережі й комунікацій між фахівцями 3 менеджменту культури й мистецтва, а також комплексних і системних наукових досліджень у цій галузі [9].

Не припустимим, на нашу думку, є те, що в Україні майже відсутня інформація про освіту 3 менеджменту культури й музичного мистецтва, яка здійснюється в зарубіжних університетах. Дослідження, спрямовані на поповнення такої інформації, повинні передбачати ретельне вивчення типів існуючих програм, академічних та неакадемічних, їх потужності, змісту, мети навчання і результатів, а також методичних прийомів.

Як наслідок, фахівці $з$ менеджменту культури й музичного мистецтва стикаються 3 невеликим вибором програм, придатних для їх потреб. Чинні програми менеджменту культури, ураховуючи їх суперечливий зміст, навряд чи можуть задовольнити зростаючі вимоги закладів культури до кваліфікації менеджерів, що потребує вдосконалення та розробки нових програм. Розвиток можливостей у менеджменті культури для фахівців із культурної політики й управлінців галузі культури має передбачити вміння і спосіб реагування на виклики таких процесів, як глобалізація, демократизація і ринкові перетворення. Розв'язання зазначених проблем, наголошує О. Часник, дозволить підвищити якість підготовки фахівців 3 мистецького менеджменту, сприятиме підвищенню престижності професії митця [9].

Ураховуючи творчі здобутки вітчизняних фахівців з мененджменту культури [5], передовий досвід зарубіжних університетів щодо впровадження програм з мистецького мененджменту [9; 10], а також їх відсутність у вітчизняних вищих музичних навчальних закладах, збагачення змісту фахової освіти студентів музичних спеціальностей теоретичними питаннями арт-менеджменту ми вважаємо першою необхідною педагогічною умовою формування в них відповідної професійної компетентності.

Суттєвим $є$ те, що з урахуванням переліку функціональних компетенцій та відповідних 
особистісних якостей сучасного арт-менеджера, слід спроектувати більш дієву модель його фахової підготовки, застосовуючи передусім нові педагогічні технології й засоби навчання. Зумовлено це тим, що професійна підготовка ефективного арт-менеджера потребує зміщення акцентів в освітньому процесі з викладання як трансляції «готового знання» на учіння, яке передбачає самостійне набуття ним певних функціональних компетенцій, зокрема, шляхом грунтовного опанування провідних технологій арт-мененджменту. Серед них, зазначають О. Командишко [2], Г. Новікова [4], Г. Тульчинский [7], найбільш дієвими видаються такі:

- організаційно-управлінські і маркетингові технології, що забезпечують процеси планування, організації, реалізації та мотивації роботи виконавців для здійснення конкретних культурних проектів та видів художньої, музичної діяльності, а також розробку стратегій розвитку освітніх установ культури і мистецтва. Вони спрямовані на оцінювання ефективності управлінських рішень в системі підготовки кадрів культури, конкретизацію маркетингової стратегії установ, планування і здійснення заходів, спрямованих на вивчення потреб ринку праці у фахівцях соціокультурного профілю;

- освітні та професійно-орієнтовані технології, призначені для забезпечення єдності цілей, завдань, мотивів і способів освітньої діяльності тих, хто навчається, під час реалізації основних освітніх програм художнього, соціокультурного, культурологічного та мистецтвознавчого профілю;

- творчо-розвивальні, які через вплив на емоційно-почуттєву сферу, позитивно впливають на процес виховання духовності, ціннісних орієнтацій, культури почуттів, розвитку пізнавальних здібностей особистості;

- комунікативні технології, що передбачають створення ефективної комунікативної інфраструктури освітнього закладу, забезпечення внутрішньої і зовнішньої комунікації, формування та забезпечення високого рівня корпоративної культури, а також діяльність 3 поліпшення взаємовідносин між учасниками освітнього простору та громадськістю, координовані зусилля щодо створення сприятливого уявлення про систему підготовки кадрів культури;

- технології реклами і громадських зв'язків, спрямованих на розробку, підготовку до випуску, виробництво і поширення рекламної продукції про можливості професійної освіти в галузі мененджменту культури i музичного мистецтва, формування або підтримка професійного інтересу до нових спеціальностей мистецького та соціокультурного профілю;

- event-технології, засновані на психолого-педагогічних закономірностях розважально-ігрової та художньо-видовищної діяльності, організації подієвих акцій, проведенні знакових заходів про систему підготовки нових кадрів для сфери культури, що мають аксіологічну, соціокультурну та виховну функції та психологічне навантаження, сприяючи формуванню позитивного образу арт-мененджера як фахівця соціально-культурної та художньої діяльності;

- publicity-технології, засновані на стимулюванні ефективного іміджу освітньої установи шляхом поширення позитивної інформації про іiі діяльність і реалізації цільового орієнтиру пропаганди - доброзичливого ставлення до навчального закладу з боку різних груп інтересів [4, с. 57-59].

3 огляду на зазначене вище, організацію самостійно-дослідницької діяльності студентів музичних спеціальностей з опанування провідних технологій арт-менеджменту вважаємо другою необхідною умовою формування в них відповідної професійної компетентності. Для іiі створення доцільно впроваджувати засоби студентоцентрованого навчання, сутність якого зумовлюють такі особливості: має місце зміщення акцентів від викладача і того, що викладається, до студента i до того, що вивчається; домінують гуманістичні педагогічні відносини, в силу чого викладач стає «помічником-фасилітатором», де відповідальність за навчання спільна, а зміст освіти і способи викладання обговорюються в діалоговому режимі; студенти розглядаються як особистості, які розвиваються, оскільки враховується їхній досвід, особливості, здібності сприйняття, інтереси і потреби; студенти самостійно «проектують» свій власний освітній маршрут за допомогою активного учіння, 
рефлексії, а також самостійних розвідок, знахідок і відкриттів; студенти залучені до процесу самостійного вибору того, що вивчати i в якому режимі й послідовності, навчання зорієнтовано як на прикінцеві результати, так і на вихідні чинники; процес навчання насичено не тільки передачею знань, а більш глибоким розумінням сутності освіти задля формування критичного мислення студентів, актуалізації їх рефлексії; студенти орієнтуються на навчання протягом усього життя шляхом перебування в різних освітніх ситуаціях і співучасті в активних та інтерактивних формах освіти [1, с. 25-27].

Студентоцентроване навчання зумовлює передусім кардинальну зміну ролі викладача, способів формулювання ним своїх професійно-педагогічних завдань згідно 3 новими освітніми програмами на основі компетентнісної спрямованості, особистісно-розвивальної орієнтації, уведення системи залікових одиниць, урахування компетенцій як одного 3 головних структурних принципів організації освітнього процесу. Під час студентоцентрованого навчання викладач покликаний забезпечити як збереження свого рольового статусу, так і більш високий рівень консультування і мотивування тих, хто навчається, у питаннях відбору інформації та тлумачення іiі джерел, організації адекватних навчальних ситуацій, ліквідації виявлених прогалин [1, с. 37]. Це передбачає вияв більш високої мотивації студентів до навчання професії арт-менеджера, яка формується не лише в академічній сфері. Як наслідок, педагогічна підтримка особистісно-професійного саморозвитку студентів як арт-мененджерів у галузі музичного мистецтва має стати третьою необхідною умовою формування в них професійної компетентності з арт-менеджменту.

В означеному контексті студентоцентроване навчання арт-мененджменту сприяє тому, щоб студенти музичних спеціальностей виявляли свою самостійність у виборі шляхів освоєння навчального матеріалу через формування індивідуального освітнього маршруту, зумовленого особистими потребами та можливостями. При цьому критичне мислення майбутнього арт-менеджера вже під час професійної підготовки, заснованої на принципах студентоцентрованого навчання, стає однією 3 найважливіших якостей його творчої особистості, яка $\epsilon$ необхідною умовою іï успішного соціального i професійного функціонування. Систематичний «вихід» студентів як майбутніх арт-менеджерів у рефлексивну позицію дозволяє виявити їх особистісні зміни, простежити динаміку особистісного розвитку, що суттєво впливає на здобуття ними необхідних професійних компетенцій. Студентоцентроване навчання, сприяючи диференціації навчальної діяльності студентів музичних спеціальностей як майбутніх арт-менеджерів, реалізації індивідуальної траєкторії їх освіти уможливлює значне підвищення іiї якості, оскільки акцент переноситься від навчання «для всіх» до навчання «для мене», що значно мотивує досягнення найвищих прикінцевих результатів. Тому спонукання студентів музичних спеціальностей до участі в різних видах проектної художньо-творчої діяльності постає четвертою педагогічною умовою формування в них професійної компетентності з арт-менеджменту.

Формування професійної компетентності студентів музичних спеціальностей 3 артменеджменту під час здобуття мистецької освіти відбуватиметься більш ефективно, якщо в навчально-виховному процесі вдасться створити певні педагогічні умови. Їх практичній реалізації сприяють засоби студентоцентрованого підходу.

\section{Література}

1. Дроздова Н. В. Компетентностный подход как новая парадигма студентоцентрированного образования / Н. В. Дроздова, А. П. Лобанов. - Минск : РИВШ, 2007. - 100 с. 2. Командышко Е. Ф. Арт-менеджмент: специфика, проблемы, перспективы развития / Е. Ф. Командышко. - Москва : ИХО РАО, 2009. - 216 с. 3. Лідстоун Дж. Сучасні методики формування навчальних програм 3 менеджменту культури i мистецтв / Дж. Лідстоун // Арт-менеджмент: Все про мистецтво управління мистецтвом. - 2007. - № 12. - С. 9-12. 4. Новикова Г. Н. Технологии арт-менеджмента: [учеб. пособие] / Г. Н. Новикова. - Москва : Издательский Дом МГУКИ, 2006. - 122 с. 5. Проблеми мистецької освіти: Типологічні критерії та науково-методична розробка/ Інститут культурології Академії мистецтв України; авт. кол. : Безгін О. І. (кер. авт. колективу), 
Бернадська Г. С., Дацко О. І., Кочарян І. С., Успенська О. Ю. - Київ : СПД Голосуй, 2008. 138 с. 6. Річ Дж. Денніс. Розвиток освіти 3 арт-менеджменту в країнах 3 перехідною економікою / Річ Дж. Денніс Річ, П. Дьюї // Арт-менеджмент: Все про мистецтво управління мистецтвом. - 2005. - № 2. - С. 7-11. 7. Тульчинский Г. Л. Менеджмент в сфере культуры : [учеб. пособие]. - / Г. Л. Тульчинский, Е. Л. Шекова. - Санкт-Петербург : Лань; ПЛАНЕТА МУЗЫКИ, 2009. - 528 с. 8. Чижиков В. В. Теория и практика социокультурного менеджмента : [учеб. пособие] / В. В. Чижиков, В. М. Чижиков. - Москва : МГУКИ, 2008. 608 с. 9. Часник О. Навчальні програми 3 арт-мененджменту в університетах США / О.Часник // Вісник ХДАК, 2010. - Вип. 30. - С. 46-51. 10. Assosiation of Arts Administration Educators [Електронний ресурс]. - Режим доступу: www.artsadmin istration.org. 11. Bendixen P. Skills and Roles: Concepts of Modern Arts Management / P. Bendixen // International Journal of Arts Management/-Vol. 2. - № 3. - 2005 (abstract). [Електронний pecypc]. - Режим доступу: www.gestiondesarts.com /index.php.

УДК 378:784

Ху Манлі

\section{ЕКСПЕРИМЕНТАЛЬНА ПЕРЕВІРКА ЕФЕКТИВНОСТІ МЕТОДИКИ ПІДГОТОВКИ КЕРІВНИКА ВОКАЛЬНОГО АНСАМБЛЮ}

Ху Манлі. Експериментальна перевірка ефективності методики підготовки керівника вокального ансамблю.

У статті розкривається ефективність авторської методики, запропонованої для фахової підготовки вчителя музики - керівника вокального ансамблю в системі вищої музичнопедагогічної освіти України та Китаю. Визначено завдання формувального експерименту. Вибір методів, залучених до експериментального дослідження, пов'язаний із необхідністю отримання достовірних даних, які б засвідчили динаміку змін та ефективність системи вищої музично-педагогічної освіти, іiі відповідність вимогам щодо ролі та функцій освіти в підготовці майбутніх керівників вокального ансамблю завдяки впровадженню розробленої нами методики. Висвітлено основні етапи формування методичної підготовленості студентів до керівництва вокальним ансамблем.

Ключові слова: методика, формувальний експеримент, керівник вокального ансамблю, навчально-виховний процес, спецкурс.

Ху Манли. Экспериментальная проверка эффективности методики подготовки руководителя вокального ансамбля.

В статье исследуется эффективность авторской методики, предложенной для специальной подготовки учителя музыки - руководителя вокального ансамбля. Рассмотрены задания формирующего эксперимента. Выбор методов, использованных при проведении экспериментального исследования, взаимосвязан с необходимостью получения достоверных данных, которые помогают зафиксировать динамику изменений, эффективность системы высшего музыкально-педагогического образования Украины и Китая. Освещаются основные этапы формирования методической подготовленности студентов к осуществлению руководства вокальным ансамблем.

Ключевые слова: методика, формирующий експеримент, руководитель вокального ансамбля, учебно-воспитательный процесс, спецкурс.

Hu Manley. Experimental verification of the effectiveness of methods of training the head of a vocal ensemble.

The article reveals the effectiveness of the methodology proposed for professional training of music teacher as a guide of a vocal ensemble in higher musical and pedagogical education in Ukraine and China. The article presents peculiarities of experimental verification of the effectiveness of methods of training the guide of a vocal ensemble. At ascertaining experiment, we 